\title{
Genetic strain and diet effects on grazing behavior, pasture intake, and milk production
}

\author{
A. J. Sheahan, ${ }^{1}$ E. S. Kolver, and J. R. Roche \\ DairyNZ, Private Bag 3221, Hamilton, New Zealand
}

\begin{abstract}
Understanding how dairy cows adjust their grazing behavior in response to feed supplements is important for the development of management strategies that optimize profit from supplementation. New Zealand Holstein-Friesian (HF) cows have been selected for milk production on a predominantly pasture-based diet; in comparison, HF cows of North American (NA) ancestry have been selected almost exclusively for milk yield and fed diets high in nonfiber carbohydrates (NFC). We hypothesized, therefore, that supplementation would have differing effects on grazing behavior, pasture dry matter intake (DMI), and milk production in these genetic strains at peak, mid, and late lactation. A study was conducted over 2 consecutive lactations, with NA and $\mathrm{NZ}$ cows randomly allocated at calving to 0,3 , or $6 \mathrm{~kg}$ of dry matter/day concentrate plus unrestricted access to pasture. Pasture DMI, milk production, and grazing behavior were recorded at peak, mid, and late lactation. Concentrates were fed in equal amounts at morning and afternoon milking. The NA cows produced more milk and milk components, and had a greater pasture DMI, despite spending less time grazing. Declines in time spent grazing and pasture DMI were associated with increasing concentrate DMI. Grazing behavior following morning supplementation was different from that recorded following afternoon supplementation. Grazing ceased following morning supplementation before rumen fill could be a limiting factor, and the length of the grazing interval was inversely proportional to the amount of concentrate offered; these results suggest that physiological rather than physical stimuli were responsible for grazing cessation. The decrease in time spent grazing with increasing concentrate DMI is consistent with changes in neuroendocrine factors secreted in response to the presence of food in the digestive tract or with circulating products of digestion. After afternoon supplementation, sunset signaled the end of grazing irrespective of stage of lactation, timing of sunset,
\end{abstract}

Received December 13, 2010.

Accepted March 21, 2011.

${ }^{1}$ Corresponding author: angela.sheahan@dairynz.co.nz or supplementation status, suggesting that photoperiod influenced grazing behavior. Results confirmed changes in grazing behavior, an associated reduction in pasture DMI, and an increase in milk production when cows consume increasing amounts of concentrates. However, as the effect of supplement on grazing behavior differed between morning and afternoon supplementation, further research is required to better understand the factors controlling grazing behavior, to allow improved milk production responses to supplementary feeding.

Key words: substitution rate, Holstein-Friesian strain, stage of lactation

\section{INTRODUCTION}

Low DMI is a major limitation to productivity in pasture-based dairy systems, resulting in nutrient intakes that are insufficient to exploit the genetic capability of the lactating cow for milk production (Kolver and Muller, 1998). Understanding how cows adjust their grazing behavior to contend with the changing environment and forage dynamics is important for the development of management strategies that optimize dairy cow production (Demment et al., 1986). For example, the objective of feeding supplements to grazing cows is to increase total DM and ME intakes, compared with those achieved on pasture alone (Stockdale, 2000). However, feeding supplements can have a marked effect on pasture DMI, with pasture DMI reported to decline with increasing supplementation (Bargo et al., 2003).

The decline in pasture consumed relative to the amount of supplement eaten is referred to as substitution and can result in poor marginal responses to the supplement provided. Bargo et al. (2003) reported that, on average, feeding concentrates reduced grazing time by $12 \mathrm{~min} / \mathrm{kg}$ of DM concentrate offered. This is a major factor contributing to the variable milk yield response to concentrate supplementation (marginal milk response: MR; Stockdale, 2000). Substitution rate (SR) has been reported to decline from spring to summer to autumn (Stockdale, 2000), suggesting that the negative effect of supplementation on grazing behavior may vary with stage of lactation or with seasonal variations in pasture quality. 
Genetic differences may also contribute to the SR and MR, as New Zealand (NZ) Holstein-Friesian (HF) cows are fed a predominantly pasture-based diet with very limited concentrate supplement, are smaller and produce less milk volume, but have better fertility and survival (Harris and Kolver, 2001). On the other hand, North American (NA) HF cows are larger and produce more milk with lower concentrations of fat and protein, but have poorer fertility and survival than NZ HF cows (Roche et al., 2006). Holstein-Friesian cows of NA ancestry were, until recently, selected almost exclusively for milk yield and fed diets high in NFC (Harris and Kolver, 2001). Previous studies comparing these strains have also reported a lower pasture DMI in NZ cows and a lower MR to supplements than their NA comparison (Horan et al., 2004; Linnane et al., 2004). The 2 HF strains, therefore, provide a comparison of the effects of genetic selection on cow behavior.

Pasture DMI depends on factors that govern commencement and cessation of successive grazing bouts (Gregorini et al., 2006). Grazing is predominantly a daylight activity, with 65 to $100 \%$ of daily grazing time reportedly between 0600 and $1900 \mathrm{~h}$ over a wide range of environmental temperatures, supplementation regimens, grazing managements, and pasture DMI (Krysl and Hess, 1993). However, this does not mean that grazing behavior is unresponsive to environmental and management cues. For example, in the morning, dairy cows interrupt their first grazing bout long before reaching maximal rumen capacity (Taweel et al., 2004) and bite rate is reported to be greatest during the evening meal, so that cows maximize DMI before darkness (Gibb et al., 1998). Although the effect of concentrates on average grazing time and bite rate has been reported (O'Connell et al., 2000; Bargo et al., 2003), little is known about differences in grazing and ruminating behavior in response to cow genetics, supplementation at different times of the day (Krysl and Hess, 1993), and stage of lactation.

This experiment investigated the effect of feeding concentrates on grazing behavior, pasture DMI, and milk production of NZ and NA HF cows at peak, mid, and late lactation over 2 yr. We hypothesized that the morning allocation of concentrates would decrease grazing time to a greater extent than the afternoon allocation, due to the findings that bite rate increases at the evening meal. To test this, grazing and ruminating activity following morning and afternoon allocations of concentrate were investigated separately.

\section{MATERIALS AND METHODS}

This experiment was conducted at Lye Farm, DairyNZ (Hamilton, New Zealand) from July 2002 to
June 2004 and all procedures were approved by the Ruakura Animal Ethics Committee (Hamilton, New Zealand).

\section{Experimental Design}

The experimental design was reported in detail by Roche et al. (2006). Briefly, over 2 yr, 54 and 59 (yr 1 and 2 , respectively) primiparous and multiparous $\mathrm{HF}$ cows of NA ( $\mathrm{n}=27$ and 29 in yr 1 and 2, respectively) and NZ ( $\mathrm{n}=27$ and 30 cows in yr 1 and 2, respectively) ancestry were randomly allocated, at calving, to 1 of 3 supplementary feeding treatments in a $2 \times 3$ factorial arrangement. Cow allocation ensured that all treatments were balanced for age $(5.1 \pm 1.60$ and $5.4 \pm 1.68$ yr in yr 1 and 2, respectively), calving date (July $28 \pm$ $19.9 \mathrm{~d}$ and July $27 \pm 26.0 \mathrm{~d}$ in yr 1 and 2, respectively), and breeding worth (measure of genetic merit accounting for the economic value of the trait; Harris et al., 1996). Cows were re-randomized at the beginning of yr 2 , ensuring that treatment groups were again balanced for the same criteria as in yr 1 .

All cows were offered $>45 \mathrm{~kg}$ of $\mathrm{DM} /$ cow per day of fresh pasture (to ground level), and 4 of the 6 treatments (2 from each genetic strain) received either 3 or $6 \mathrm{~kg} \mathrm{DM}$ of a pelleted grain-based concentrate/day. The remaining 2 treatments received no concentrate. Treatments were designated NZ0, NZ3, NZ6, NA0, NA3, and NA6.

\section{Genetic Strains}

The 2 genetic strains were described in detail by Roche et al. (2006). Briefly, the NA strain cows had $>87.5 \%$ NA genetic ancestry and were imported from either the United States or the Netherlands as embryos by Holland Genetics Ltd. for LIC, New Zealand, or were direct descendants of the imported embryos. The mean EBV for the NA cows on study were $+1,270$ (SD 246.4) $\mathrm{kg}$ of milk, +32 (SD 7.7) $\mathrm{kg}$ of fat, +39 (SD 6.4) $\mathrm{kg}$ of protein, +93 (SD 12.4) $\mathrm{kg}$ of $\mathrm{BW}$ and -40 (SD 117.1) d survival. The NZ cows used in the present experiment were selected from DairyNZ herds based on their breeding worth and the proportion of NZ ancestry $(<12.5 \%$ NA genes). The EBV for the NZ cows on study were +820 (SD 225.5) kg of milk, +29 (SD 6.95) $\mathrm{kg}$ of fat, +28 (SD 5.90) $\mathrm{kg}$ of protein, +52 (SD 15.8) $\mathrm{kg}$ of BW, and +325 (SD 79.92) d survival. Each strain represented 6 to 9 sires, which were common across feeding treatments within strain.

\section{Pasture Management and Supplementary Feeding Treatments}

Cows were rotationally grazed as one herd for the duration of the experiment and only returned to the 
same area when a minimum of 2 leaves had appeared on the majority $(>75 \%)$ of perennial ryegrass tillers. Cows had access to a fresh allocation of pasture after each milking. Pasture allowance $(>45 \mathrm{~kg}$ of $\mathrm{DM} /$ cow per d) was sufficient to ensure unrestricted DMI (up to approximately $25 \mathrm{~kg}$ of $\mathrm{DM} /$ day) of fresh pasture in the unsupplemented cows. Pasture was high quality throughout both years $(\mathrm{CP}=22.2 \pm 2.73 \% \mathrm{DM}$; OM digestibility $=84.2 \pm 3.87 \% \mathrm{DM} ; \mathrm{NDF}=40.0 \pm 4.38 \%$ $\mathrm{DM} ; \mathrm{ADF}=22.2 \pm 2.50 \% \mathrm{DM} ;$ lipid $=4.1 \pm 0.25 \%$ $\mathrm{DM} ; \mathrm{NSC}=11.3 \pm 2.50 \% \mathrm{DM} ; \mathrm{ME}=11.8 \pm 0.54$ $\mathrm{MJ} / \mathrm{kg}$ of DM). Quality was maintained throughout the season, despite the high grazing residuals, through strategic mowing.

A flat rate of either 3 or $6 \mathrm{~kg}$ DM of concentrates (60\% crushed corn; $32 \%$ crushed barley; $6 \%$ molasses; $2 \%$ wheat middlings; $\mathrm{CP}=11.2 \pm 1.46 \% \mathrm{DM}$; $\mathrm{NDF}=$ $9.8 \pm 1.99 \% \mathrm{DM} ;$ lipid $=2.7 \pm 1.22 \% \mathrm{DM} ; \mathrm{NSC}=71.9$ $\pm 2.16 \% \mathrm{DM}$ ) was fed individually to the appropriate treatments. Concentrate allocation was split equally in 2 feeds and offered daily during milking. For $15 \mathrm{~d}$ precalving, all cows were offered $2 \mathrm{~kg} \mathrm{DM} / \mathrm{d}$ concentrate. Following calving, the NZ3 and NA3 cows received $3 \mathrm{~kg}$ $\mathrm{DM} / \mathrm{d}$ concentrate and the NZ6 and NA6 were gradually stepped up to $6 \mathrm{~kg} \mathrm{DM} / \mathrm{d}$ concentrate over the following $6 \mathrm{~d}(0.5 \mathrm{~kg} \mathrm{DM} / \mathrm{d}$ concentrate).

\section{Milk Production}

Milk production results for this study are for the periods that pasture DMI and grazing behavior were analyzed. Individual milk yields were recorded daily (Westfalia Surge, Oelde, Germany). Milk fat, CP, and lactose concentrations were determined by Milkoscan (Foss Electric, Hillerød, Denmark) on a composite afternoon and morning sample collected on one day each week.

\section{Grazing Behavior}

Time spent grazing, ruminating, lying, and standing was determined by recording each cow's activity at 10min intervals throughout a 24 -h period while the cows were in the paddock (Gary et al., 1970). Grazing was defined as "cows in the act of eating." Behavior was recorded in two 24-h periods during peak (October), mid (January), and late (April) lactation in each year. This provided $4 \times 24$-h grazing periods at each stage of lactation across $2 \mathrm{yr}$. The 24 -h observation periods were further divided into 4 key periods to determine the effect of treatment on cow grazing behavior at these times. The 4 periods were period 1 (post-morning milking to afternoon milking), period 2 (post-afternoon milking to sunset), period 3 (post-sunset to $2350 \mathrm{~h}$ ), and period 4 (0000 $\mathrm{h}$ to morning milking). The duration of the primary grazing bout following morning and afternoon milking was calculated as the difference between the time each cow entered the pasture and the time immediately before the recording of 2 consecutive nongrazing behaviors.

\section{Pasture Intake Measurements}

Individual cow DMI estimates were obtained at pasture using the n-alkane technique outlined by Roche et al. (2008). Briefly, each cow was dosed twice daily (at milking) for a 10-d period with a pellet containing $356 \mathrm{mg}$ of n-dotriacontane (C32; i.e., $712 \mathrm{mg}$ of C32/ cow per day). Fecal grab samples were collected twice daily from each cow (after milking) during the last 5 $\mathrm{d}$ of the $10-\mathrm{d}$ period. The 10 fecal samples from each cow for the 5-d period were then bulked, freeze-dried, and stored at $-17^{\circ} \mathrm{C}$ awaiting alkane analysis. During the same 5-d period, pasture samples were "plucked" to grazing height on 2 occasions each day, following close observation of the grazing animal, to represent pasture grazed. A sample of the concentrate consumed was sampled at the morning and afternoon feeding event each day of the $5 \mathrm{~d}$ sampling period. The n-alkane content (C25-C36) of the pasture, supplement, and feces were determined using gas chromatography.

The ratio of pasture C33 (tritriacontane) to dosed C32 (n-dotriacontane) was used to estimate pasture DMI:

Daily pasture DMI $(\mathrm{kg} / \mathrm{cow})=\frac{F_{i} / F_{j} \cdot\left(D_{j}+I_{S} \cdot S_{j}\right)-I_{S} \cdot S_{i}}{P_{i}-\left(P_{j} \cdot F_{i} / F_{j}\right)}$,

where $F_{i}, S_{i}$, and $P_{i}$ are the concentrations $(\mathrm{mg} / \mathrm{kg}$ of $\mathrm{DM})$ of the natural odd-chain n-alkane (C33) in feces, supplement, and pasture, respectively; $F_{j}, S_{j}$, and $P_{j}$ are the concentrations $(\mathrm{mg} / \mathrm{kg}$ of $\mathrm{DM})$ of the dosed even-chain n-alkane (C32) in feces, supplements, and pasture, respectively; and $D_{j}$ and $I_{S}$ are the dose rate (mg/d) of the even-chain n-alkane (C32) and supplement DMI, respectively.

\section{Statistical Analysis}

Intake, production, and behavior summary measures were calculated. Each variable was analyzed separately using mixed models, including age group (heifer vs. cow), season (yr 1 and yr 2), genetic strain, diet, and the interaction between genetic strain and diet as fixed effects, and cow as a random effect. Mixed models were fitted using REML, and GenStat 12.1 (VSN International Ltd., Hemel Hempstead, UK) was used for 
Table 1. Pasture and total DMI ( $\mathrm{kg}$ of DM/d), milk and component yield $(\mathrm{kg} / \mathrm{d})$, and milk composition (\%) during peak, mid, and late lactation for New Zealand (NZ) and North American (NA) cows offered 0, 3, or $6 \mathrm{~kg}$ of DM/d concentrates

\begin{tabular}{|c|c|c|c|c|c|c|c|c|c|}
\hline \multirow[b]{2}{*}{ Item } & \multicolumn{2}{|c|}{ Strain } & \multicolumn{3}{|c|}{ Diet } & \multicolumn{2}{|c|}{$\mathrm{SED}^{1}$} & \multicolumn{2}{|c|}{$P$-value } \\
\hline & $\mathrm{NZ}$ & NA & 0 & 3 & 6 & Strain & Diet & Strain & Diet \\
\hline Pasture DMI & 15.59 & 16.52 & 17.19 & 15.94 & 15.04 & 0.708 & 0.804 & 0.22 & 0.03 \\
\hline Total DMI & 18.39 & 19.34 & 17.25 & 18.81 & 20.55 & 0.695 & 0.804 & 0.16 & $<0.001$ \\
\hline Milk yield & 25.54 & 29.43 & 24.95 & 28.41 & 29.10 & 0.852 & 1.033 & $<0.001$ & $<0.001$ \\
\hline Fat yield & 1.06 & 1.16 & 1.08 & 1.19 & 1.07 & 0.052 & 0.068 & 0.05 & 0.12 \\
\hline Fat $\%$ & 4.18 & 3.97 & 4.29 & 4.20 & 3.74 & 0.159 & 0.182 & 0.17 & $<0.01$ \\
\hline Protein \% & 3.46 & 3.40 & 3.38 & 3.44 & 3.47 & 0.059 & 0.056 & 0.29 & 0.25 \\
\hline Lactose \% & 4.93 & 4.92 & 4.87 & 4.93 & 4.97 & 0.044 & 0.028 & 0.86 & $<0.01$ \\
\hline \multicolumn{10}{|l|}{ Mid lactation } \\
\hline Pasture DMI & 15.25 & 18.60 & 18.51 & 16.59 & 15.67 & 0.669 & 0.662 & $<0.001$ & $<0.001$ \\
\hline Total DMI & 18.09 & 21.49 & 18.63 & 19.48 & 21.26 & 0.656 & 0.684 & $<0.001$ & $<0.001$ \\
\hline Milk yield & 20.77 & 25.20 & 19.71 & 24.04 & 25.22 & 0.667 & 0.728 & $<0.001$ & $<0.001$ \\
\hline Lactose \% & 4.88 & 4.88 & 4.85 & 4.89 & 4.91 & 0.038 & 0.034 & 0.87 & 0.26 \\
\hline \multicolumn{10}{|l|}{ Late lactation } \\
\hline Pasture DMI & 15.24 & 18.40 & 17.77 & 16.81 & 15.88 & 0.604 & 0.685 & $<0.001$ & $<0.05$ \\
\hline Total DMI & 18.13 & 21.17 & 17.86 & 19.51 & 21.58 & 0.588 & 0.673 & $<0.001$ & $<0.001$ \\
\hline Milk yield & 15.90 & 19.54 & 14.61 & 18.74 & 19.81 & 0.713 & 0.782 & $<0.001$ & $<0.001$ \\
\hline Fat yield & 0.78 & 0.85 & 0.72 & 0.85 & 0.87 & 0.034 & 0.036 & $<0.05$ & $<0.001$ \\
\hline Protein yield & 0.64 & 0.77 & 0.59 & 0.74 & 0.78 & 0.024 & 0.027 & $<0.001$ & $<0.001$ \\
\hline Lactose yield & 0.76 & 0.94 & 0.69 & 0.90 & 0.96 & 0.037 & 0.040 & $<0.001$ & $<0.001$ \\
\hline Fat $\%$ & 4.95 & 4.38 & 5.01 & 4.59 & 4.41 & 0.155 & 0.114 & $<0.001$ & $<0.001$ \\
\hline Protein \% & 4.06 & 3.94 & 4.09 & 3.94 & 3.98 & 0.074 & 0.063 & 0.11 & 0.06 \\
\hline Lactose \% & 4.74 & 4.81 & 4.72 & 4.80 & 4.82 & 0.124 & 0.072 & 0.12 & 0.07 \\
\hline
\end{tabular}

${ }^{1}$ Standard error of the difference of the means.

all statistical analyses. Summary grazing behavior as analyzed above was then converted into minutes spent grazing. Bite mass was estimated by average pasture DMI/time spent grazing. Substitution rate was calculated by regressing pasture DMI (dependent variable) against supplement DMI (independent variable) with the slope equaling SR. No significant interaction was observed between genetic strain $\times$ diet; therefore, only strain and diet effects are reported.

\section{RESULTS}

The effects of treatment on total and pasture DMI and milk production are presented in Table 1. North American cows consumed more $(P<0.001)$ pasture than NZ cows in mid and late lactation, but not in early lactation. Data indicate that NA cows reached maximum DMI later than NZ cows. Irrespective of stage of lactation, concentrate supplementation resulted in a linear increase $(P<0.001)$ in total DMI but a decline $(P<0.05)$ in pasture DMI. Substitution rates $(\mathrm{kg}$ of pasture substituted $/ \mathrm{kg}$ of concentrates consumed) differed between strains. The NZ cows had SR of 0.45
(SED 0.96), 0.72 (SED 0.02), and 0.48 (SED 0.008) in early, mid and late lactation, respectively, whereas the NA cows had SR of 0.29 (SED 0.163), 0.26 (SED 0.178 ), and 0.17 (SED 0.014) in the same lactation stages, respectively.

North American cows were heavier $(P<0.001)$ at calving, at nadir, and at the end of lactation (data not presented; see Roche et al., 2006). However, NA cows lost $26 \%$ more $(P<0.001)$ BW between calving and nadir than NZ cows (84 vs. $62 \mathrm{~kg}$ of BW). Although both strains calved at a similar BCS, NA cows had a lower $(P<0.001)$ BCS at nadir and dry off, and lost BCS for $14 \mathrm{~d}$ longer $(P<0.01)$ than NZ cows; they also gained less BCS post-nadir $(P<0.001)$. Concentrate supplementation did not affect nadir BW, but a linear increase $(P<0.05)$ in nadir BCS occurred with increasing concentrate supplementation (for more detail, see Roche et al., 2006)

Consistent with the greater pasture DMI, NA cows produced more milk $(P<0.001)$ but with lower fat and protein percentages. Consistent with the higher milk yield, NA cows had higher fat, protein, and lactose yields at all stages of lactation. Concentrate supple- 
mentation increased milk yield, but the MR was greater in the NA cows $(1.9$ and $1.1 \mathrm{~kg}$ milk $/ \mathrm{kg}$ of concentrate DM in NA cows compared with 0.8 and $0.7 \mathrm{~kg}$ of milk/ $\mathrm{kg}$ of concentrate DM in NZ cows in the 3 and $6 \mathrm{~kg}$ $\mathrm{DM} / \mathrm{d}$ groups, respectively). Irrespective of strain, MR $(1.3$ and $0.9 \mathrm{~kg}$ of milk $/ \mathrm{kg}$ of concentrate DM at 3 and $6 \mathrm{~kg}$ of $\mathrm{DM} / \mathrm{d}$, respectively) to concentrates was $31 \%$ greater, on average, in cows consuming $3 \mathrm{~kg} \mathrm{DM} / \mathrm{d}$ compared with $6 \mathrm{~kg} \mathrm{DM} / \mathrm{d}$.

Diurnal grazing and rumination patterns are presented in Figures 1 and 2, respectively, with summary data presented in Table 2. Lying and standing behavior, although recorded, is not presented. On average, $\mathrm{NZ}$ cows spent $20 \mathrm{~min} / \mathrm{d}$ more grazing and $9 \mathrm{~min} / \mathrm{d}$ less ruminating than NA cows. An increase in rumination time was recorded with increased level of concentrate. Differences were recorded during the early hours of darkness, with NZ cows spending more time grazing than NA cows (period 3; Table 2). Although NA cows spent less time grazing, their bite mass was, on average, $41 \mathrm{~g} / \mathrm{min}$ compared with $34 \mathrm{~g} / \mathrm{min}$ in NZ cows $(P<$ $0.01)$.

Time spent grazing declined linearly $(P<0.001)$ with increasing concentrate DMI. Cows supplemented with $3 \mathrm{~kg} \mathrm{DM} / \mathrm{d}$ spent 40, 35, and 28 min less grazing per day at peak, mid, and late lactation, respectively, and the cows receiving $6 \mathrm{~kg} \mathrm{DM} / \mathrm{d}$ spent 83, 74, and $84 \mathrm{~min}$ less grazing per day at peak, mid, and late lactation, respectively, compared with unsupplemented cows.

Concentrate supplementation also affected the diurnal pattern of grazing behavior. However, this effect was different following morning and afternoon feeding episodes. Following the morning milking a linear reduction in the duration of the initial grazing bout occurred with increasing concentrate supplementation (Table 2). However, the length of the first grazing bout following afternoon milking was not affected by concentrate supplementation, except during mid lactation, when it declined linearly with increasing supplementation (Table 2).

A stimulus to cease grazing at sunset occurred at all stages of lactation, even though the timing of sunset differed by up to $2.5 \mathrm{~h}$ (Figure 1). Time spent grazing during darkness declined linearly with increasing concentrate supplementation during early and late lactation (periods 3 and 4; Table 2), and mid lactation (period 4; Table 2).

\section{DISCUSSION}

The objective of this study was to examine the grazing behavior of cows differing in their genetic ancestry and consuming different amounts of concentrates. Although previous studies have reported average daily behavior data, highlighting the total daily time spent grazing and ruminating, the current study investigated the diurnal patterns of grazing behavior, thereby providing a greater understanding of when supplementation affects the diurnal profile.

Milk production and pasture DMI data are consistent with previous studies comparing similar genetic strains (Kolver et al., 2002; Kennedy et al., 2003; Horan et al., 2004; Linnane et al., 2004). North American cows grazed for less time but had greater pasture and total DMI in mid and late lactation than their NZ counterparts. The difference in pasture DMI, therefore, reflects the greater average bite mass by NA cows. Of particular note was the similar pasture DMI of NA and NZ cows in early lactation, even though the NA cows were producing $13 \%$ more milk. Data presented indicate that NZ cows reach peak DMI earlier than NA cows, and the results are consistent with the reported predisposition of NA cows to lose more BCS in early lactation (Roche et al., 2006; McCarthy et al., 2007).

Previously it has been reported that increasing the amount of supplement negatively affects pasture DMI, when pasture is not limited (Stockdale, 2000; Gekara et al., 2001; Kennedy et al., 2003; Horan et al., 2004). It has also been demonstrated that SR is poorly related to level of concentrate feeding, instead reflecting the energy balance of cows not being supplemented (Delaby, 2001). The decreased energy balance in highgenetic-merit cows during early lactation is primarily the result of genetically controlled energy partitioning rather than the result of pasture intake not keeping up with milk yield (Horan et al., 2004; Roche et al., 2009). These results suggest that SR should not increase with increasing supplement in high-genetic-merit cows or in cows where energy balance is not improved through supplementation. As the NA cows produced more milk and were in greater negative energy balance in early lactation, a lower SR was predicted. Results from the current study confirm this with SR lower in NA cows than NZ cows when consuming concentrate, providing further support that substitution is lower in high-yielding cows when energy requirements are not being met (Dixon and Stockdale, 1999; Bargo et al., 2003; Horan et al., 2004).

Distinct grazing bouts were evident within the day, with grazing occurring predominantly during daylight hours, as has been reported previously (Hafez, 1969; Krysl and Hess, 1993). However, despite this predominate diurnal pattern, grazing did occur during darkness with an average of 52,47 , and 36 min spent grazing in the 0,3 and $6 \mathrm{~kg} \mathrm{DM} / \mathrm{d}$ groups, respectively. Grazing behavior data indicate that the major grazing bouts follow morning and afternoon milking, with a greater amount of time spent grazing between afternoon and 

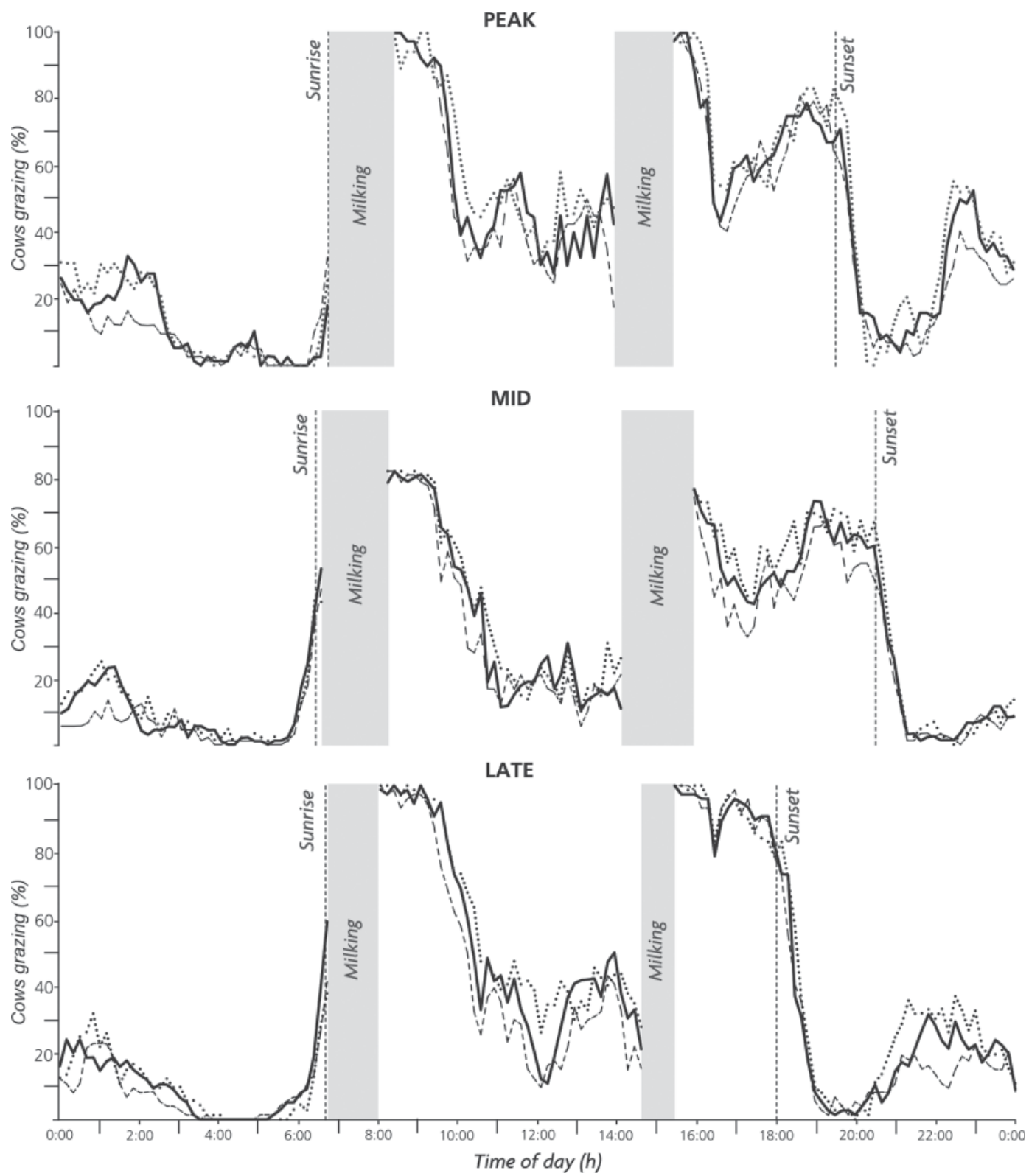

Figure 1. Diurnal profile of cows grazing during peak, mid, and late lactation when offered 0,3 , or $6 \mathrm{~kg} D M / \mathrm{d}$ concentrate $(0 \mathrm{~kg} \mathrm{DM} / \mathrm{d}=$ dotted line, $3 \mathrm{~kg} \mathrm{DM} / \mathrm{d}=$ solid line, and $6 \mathrm{~kg} \mathrm{DM} / \mathrm{d}=$ dashed line). Shading represents milking time and vertical dashed lines represent sunrise and sunset.

morning milking, as was reported by Soriano et al. (2000), and Scaglia et al. (2009), probably because of the greater amount of time available.

The grazing profile indicated a linear decline in grazing time with increasing concentrates in the first grazing bout following morning milking, consistent with the reduced pasture DMI. In comparison, no association was found between length of time in the first grazing bout following afternoon milking and amount of concentrate offered, except in mid lactation, indicating that different factors appear to interrupt grazing following morning and afternoon feeding.

If one were to assume that less than $50 \%$ of pasture DMI occurred between morning and afternoon milking, as reflected by the grazing profile, cows consumed less than $8 \mathrm{~kg}$ of DM pasture following morning milking. This is approximately 50 to $60 \mathrm{~kg}$ of fresh pasture, well below rumen capacity, and suggests that rumen fill is unlikely to be the factor responsible for interrupting grazing between morning and afternoon milking. 

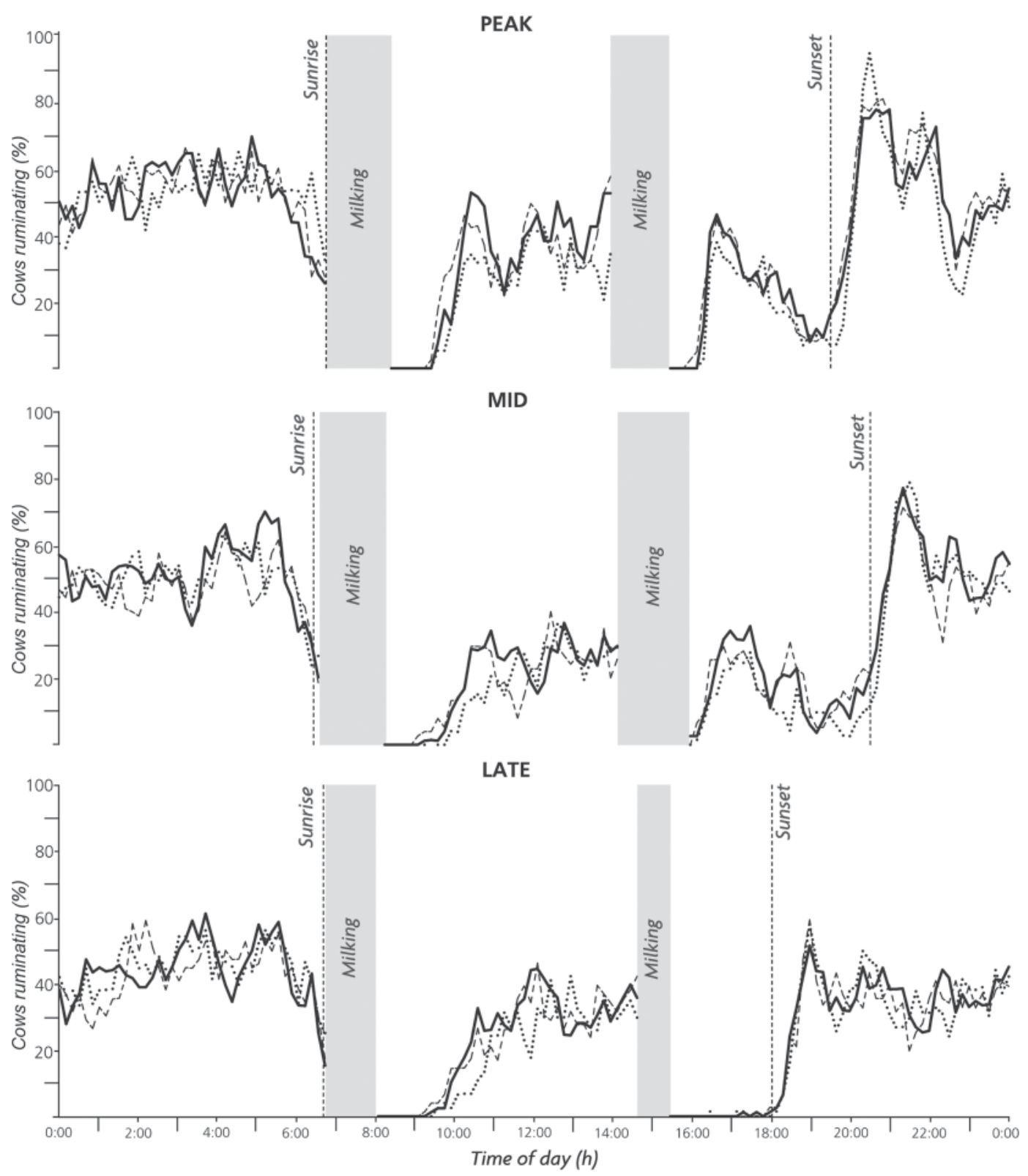

Figure 2. Diurnal profile of rumination in cows during peak, mid, and late lactation when offered 0,3 , or $6 \mathrm{~kg} \mathrm{DM} / \mathrm{d}$ concentrate $(0 \mathrm{~kg}$ $\mathrm{DM} / \mathrm{d}=$ dotted line, $3 \mathrm{~kg} \mathrm{DM} / \mathrm{d}=$ solid line, and $6 \mathrm{~kg} \mathrm{DM} / \mathrm{d}=$ dashed line). Shading represents milking time and vertical dashed lines represent sunrise and sunset.

A plausible explanation for the cessation of grazing following morning milking, therefore, could be neuroendocrine factors secreted in response to the presence of food in the digestive tract or to products of digestion; for example, propionate, as reported by Faverdin (1999), is implicated as a satiety factor. Several neuroendocrine proteins have been associated with a hunger or satiety role, their release coincident with the beginning or cessation of a meal (Roche et al., 2008). For example, Roche et al. (2007) reported that circulating ghrelin concentrations before feeding were not affected by concentrate supplementation, but increasing supplementation at the morning milking was associated with a linear decline in postprandial ghrelin concentrations, offering a potential neuroendocrine basis for reduced grazing time and the subsequent reduction in pasture DMI when supplements are offered. Although Roche et al. (2007) investigated only one peptide associated with feed intake, this finding provides a possible explanation for why supplemented cows ceased grazing earlier than unsupplemented cows in a dose-dependent way in this study. The lack of information for ruminants on pep- 
Table 2. Summary of grazing and ruminating behavior (min) during peak, mid, and late lactation for New Zealand (NZ) and North American (NA) cows offered 0,3 , or $6 \mathrm{~kg}$ of $\mathrm{DM} / \mathrm{d}$ concentrates

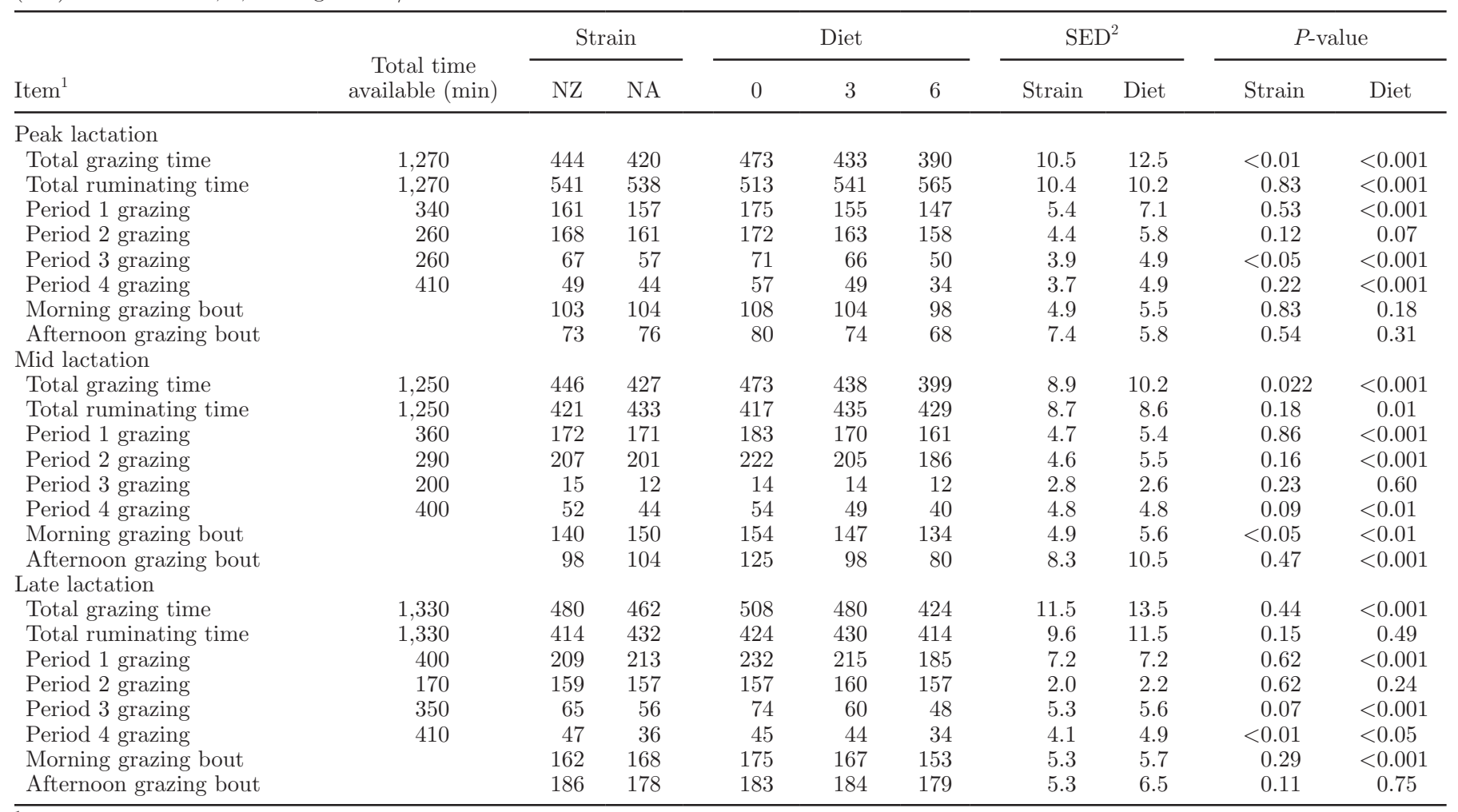

${ }^{1}$ Total time spent grazing or ruminating does not include time cows were off pasture, at milking. Period $1=$ post-morning milking to afternoon milking, period 2: post-afternoon milking to sunset, period 3: post-sunset to $2350 \mathrm{~h}$, period 4: $0000 \mathrm{~h}$ to morning milking. Morning and afternoon grazing bout $=$ duration of first grazing bout after morning or afternoon concentrate allocation.

${ }^{2}$ Standard error of the difference of the means.

tides associated with feed intake in monogastric species warrants further work.

In contrast to the profile of grazing behavior following the morning feeding episode, data indicate that cessation of grazing in the afternoon is likely a photoperiod effect, with sunset being the signal to cease grazing, regardless of supplementation, stage of lactation, or, interestingly, timing of sunset. If neuroendocrine factors did result in a cessation of grazing between morning and afternoon milking, results indicate that the anticipated arrival of darkness overrides these signals following the afternoon feed. This is supported by findings of Gibb et al. (1998) and Rutter et al. (2002), who reported that cows reduce mastication time and increase bite rate, and, thereby, increase pasture DMI later in the afternoon.

Other authors (Taweel et al., 2004; Gregorini et al., 2006) have reported that rumen fill signals the cessation of grazing following the afternoon feed. This may be true when day length is long, as was the case in the study by Taweel et al. (2004), with the dusk grazing bout ceasing at $2200 \mathrm{~h}$, allowing cows to achieve rumen fill. However, it is not the reason for the cessation of grazing in early or late lactation in the study reported here, when day length was short. Nevertheless, the observation that rumen fill was coincident with the end of the afternoon grazing bout during long day periods could help explain why concentrates reduced the length of the first afternoon grazing bout during mid lactation but not at peak or late lactation. During mid lactation, time from afternoon milking to sunset was $4.7 \mathrm{~h}$ compared with 4.2 and $2.7 \mathrm{~h}$ at peak and late lactation, respectively, thereby, providing the cow with sufficient time to reach rumen fill before sunset. During late lactation, when day length was shortest, cows adjusted their grazing behavior by grazing for longer in the morning, as if instinctively aware of the shorter period for grazing following the afternoon milking. This compensation in grazing behavior during times of shorter day length is further evidence that DMI is regulated physiologically from energy balance signals and is only limited by rumen fill during the afternoon feed during long day cycles. Further evidence for the physiological regulation of DMI in dairy cows is the linear decline in grazing during darkness associated with increasing amounts of supplementation. Results from this study 
indicate a possible satiety effect from the products of digestion from supplementation, with resulting differences in time spent grazing and pasture DMI, when supplements are offered to grazing dairy cows.

\section{CONCLUSIONS}

Grazing behavior is affected by cow genetics, day length, and the feeding of concentrates, with grazing prioritized more in the afternoon before impending darkness than in the morning after milking. Sunrise and sunset are major stimuli for the beginning and cessation of grazing, respectively. Physiological factors appear to interrupt morning grazing and this occurs earlier in cows fed supplements. Further research is required to determine the physiological factors regulating this satiety response to supplements.

\section{ACKNOWLEDGMENTS}

The authors acknowledge the technical assistance and contributions from P. Thorne, P. Aspin, DairyNZ Lye farm staff, and J. Gibbs (Lincoln University, Canterbury, New Zealand), along with B. Dow (Dairy NZ) for statistical analysis. This work was funded by New Zealand farmers through DairyNZ Inc. (Hamilton, New Zealand).

\section{REFERENCES}

Bargo, F., L. D. Muller, E. S. Kolver, and J. E. Delahoy. 2003. Invited review: Production and digestion of supplemented dairy cows on pasture. J. Dairy Sci. 86:1-42.

Delaby, L. P., J. L. Peyraud, and R. Delagarde., 2001. Effect of the level of concentrate supplementation, herbage allowance and milk yield at turn-out on the performance of dairy cows in mid lactation at grazing. Anim. Sci. 73:171-181.

Demment, M. W., E. A. Laca, and G. B. Greenwood. 1986. Intake in grazing ruminants: A conceptual framework. Pages 208-225 in Feed Intake by Beef Cattle. F. N. Owens, ed. Oklahoma Agric. Exp. Sta., Stillwater.

Dixon, R. M., and C. R. Stockdale. 1999. Associative effects between forages and grains: Consequences for feed utilization. Aust. J. Agric. Res. 50: 757-773.

Faverdin, P. 1999. The effect of nutrients on feed intake in ruminants. Proc. Nutr. Soc. 58:523-531.

Gary, L. A., G. W. Sherritt, and E. B. Hale. 1970. Behavior of Charolais cattle on pasture. J. Anim. Sci. 30:203-206.

Gekara, J., E. C. Prigge, W. B. Bryan, M. Schettini, E. L. Nestor, and E. C. Townsend. 2001. Influence of pasture sward height and concentrate supplementation on intake, digestibility, and grazing time of lactating beef cows. J. Anim. Sci. 79:745-752.

Gibb, M. J., C. A. Huckle, and R. Nuthall. 1998. Effect of time of day on grazing behavior by lactating dairy cows. Grass Forage Sci. 53:41-46.

Gregorini, P., S. A. Gunter, and C. A. Masino. 2006. Daily grazing patterns of cattle: A behavioral overview. Prof. Anim. Sci. 22:201-209.
Hafez, E. S. E. 1969. The Behavior of Domestic Animals. The Williams and Wilkins Company, Baltimore, MD.

Harris, B. L., J. M. Clark, and R. G. Jackson. 1996. Across-breed evaluation of dairy cattle. Proc. N.Z. Soc. Anim. Prod. 56:12-15.

Harris, B. L., and E. S. Kolver. 2001. Review of holsteinization of intensive pastoral dairy farming in New Zealand. J. Dairy Sci. 84:56-61.

Horan, B., J. F. Mee, M. Rath, P. O'Connor, and P. Dillon. 2004. The effect of strain of Holstein-Friesian cow and feeding systems on reproductive performance in seasonal-calving milk production systems. Anim. Sci. 79:453-467.

Kennedy, J., P. Dillon, L. Delaby, P. Faverdin, G. Stakelum, and M. Rath. 2003. Effect of genetic merit and concentrate supplementation on grass intake and milk production with Holstein Friesian dairy cows. J. Dairy Sci. 86:610-621.

Kolver, E. S., and L. D. Muller. 1998. Performance and nutrient intake of high producing Holstein cows consuming pasture or a total mixed ration. J. Dairy Sci. 81:1403-1411.

Kolver, E. S., J. R. Roche, M. J. de Veth, and A. R. Napper. 2002. Total mixed rations versus pasture diets; Evidence for a genotype $\times$ diet interaction in dairy cow performance. Proc. N.Z. Soc. Anim. Prod. 62:246-251.

Krysl, L. J., and B. W. Hess. 1993. Influence of supplementation on behavior of grazing cattle. J. Anim. Sci. 71:2546-2555.

Linnane, M., B. Horan, J. M. Connolly, P. O'Connor, F. Buckley, and P. Dillon. 2004. The effect of strain of Holstein-Friesian and feeding system on grazing behavior, herbage intake and productivity in the first lactation. Anim. Sci. 78:169-178.

McCarthy, S., D. P. Berry, P. Dillon, M. Rath, and B. Horan. 2007. Influence of Holstein-Friesian strain and feed system on body weight and body condition score lactation profiles. J. Dairy Sci. 90:1859-1869.

O'Connell, J. M., F. Buckley, M. Rath, and P. Dillon. 2000. The effects of cow genetic merit and feeding treatment on milk production, herbage intake and grazing behavior of dairy cows. Ir. J. Agric. Food Res. 39:369-381.

Roche, J. R., D. P. Berry, and E. S. Kolver. 2006. Holstein-Friesian strain and feed effects on milk production, body weight, and body condition score profiles in grazing dairy cows. J. Dairy Sci. 89:3532-3543.

Roche, J. R., D. Blache, D. R. Miller, J. K. Kay, A. J. Sheahan, and D. W. Miller. 2008. Neuroendocrine and physiological regulation of intake in domesticated ruminants: A review. Nutr. Res. Rev. 21:207-234.

Roche, J. R., N. C. Friggens, J. K. Kay, M. W. Fisher, K. J. Stafford, and D. P. Berry. 2009. Invited review: Body condition score and its association with dairy cow productivity, health, and welfare . J. Dairy Sci. 92:5769-5801.

Roche, J. R., A. J. Sheahan, L. M. Chagas, and D. P. Berry. 2007. Concentrate supplementation reduces postprandial plasma ghrelin in grazing dairy cows: A possible neuroendocrine basis for reduced pasture intake in supplemented cows. J. Dairy Sci. 90:1354-1363.

Rutter, S. M., R. J. Orr, P. D. Penning, N. H. Yarrow, and R. A. Champion. 2002. Ingestive behaviour of heifers grazing monocultures of ryegrass or white clover. Appl. Anim. Behav. Sci. 76:1-9.

Scaglia, G., H. T. Boland, and W. E. Wyatt. 2009. Effects of time of supplementation on beef stocker calves grazing ryegrass. II. Grazing behavior and dry matter intake. Prof. Anim. Sci. 25:749-756.

Soriano, F. D., C. E. Polan, and C. N. Miller. 2000. Milk production and composition, rumen fermentation parameters, and grazing behavior of dairy cows supplemented with different forms and amounts of corn grain. J. Dairy Sci. 83:1520-1529.

Stockdale, C. R. 2000. Levels of pasture substitution when concentrates are fed to grazing dairy cows in Northern Victoria. Aust. J. Exp. Agric. 40:913-921.

Taweel, H. Z., B. M. Tas, J. Dijkstra, and S. Tamminga. 2004. Intake regulation and grazing behavior of dairy cows under continuous stocking. J. Dairy Sci. 87:3417-3427. 